Studies of the Industrial Geography Commission of the Polish Geographical Society

29(3) • 2015

BożENA WÓJTOWICZ

Uniwersytet Pedagogiczny, Kraków, Polska • Pedagogical University of Cracow, Poland

Pawee Wójtowicz

Netlier Paweł Wójtowicz, Kielce, Polska • Netlier Paweł Wójtowicz, Kielce, Poland

\title{
Atrakcje turystyczne Jordanii i ich znaczenie dla rozwoju ustug turystycznych
}

\section{Tourist attractions in Jordan and their importance for development of tourist services}

Streszczenie: Jordania to państwo muzułmańskie leżące na Półwyspie Arabskim, posiadające różnorodne walory turystyczne, antropogeniczne - związane z historią i kulturą, a także przyrodnicze - związane m.in. ze zjawiskami geologicznymi. Istotną rolę gospodarczą odgrywa w nim turystyka, rozwinięta przez specjalistów brytyjskich na zlecenie króla, z dobrze przemyślaną infrastrukturą i bogatym wachlarzem usług. $Z$ uwagi na fakt, iż znaczna część BIZ (bezpośrednich inwestycji zagranicznych) ulokowana została w projektach inwestycyjnych z branży turystycznej i hotelarskiej, należy oczekiwać, że w przyszłości znaczenie sektora turystycznego w gospodarce jordańskiej będzie stale wzrastało. Ponieważ o potencjale rozwoju gospodarki turystycznej tego kraju stanowią walory przyrodnicze, w referacie przedstawiono najatrakcyjniejsze z nich, takie jak: Petra, pustynia Wadi Rum, Morze Martwe, Akaba, Amman. W tym celu dokonano analizy destynacji ruchu turystycznego, profilów turystów, sezonowości ruchu turystycznego do tych obiektów, zakwaterowania i dochodów z turystyki oraz zatrudnienia w sektorze usług. Celem referatu była analiza rynku turystycznego Jordanii na tle innych krajów Bliskiego Wschodu i perspektywy dalszego jej rozwoju.

\begin{abstract}
Jordan is an Muslim country situated on the Arabian Peninsula, which has a variety of tourist and anthropogenic attractions related to the history, culture, as well as nature-based attractions inter alia on geological phenomena. The important economic role is played by tourism, developed by British experts commissioned by the King, with a well thought infrastructure and a rich range of different services. Due to the fact that a significant part of the FDI (Foreign Direct Investment) has been placed in investment projects related to the tourism industry and the hospitality industry (hotel industry), it is expected that the significance of the tourism sector in the Jordanian economy will continue to grow in the future. As a consequence, since the potential development of the tourist economy of this country refers to the natural values, this paper presents the most attractive ones, namely Petra, the Wadi-Rum Desert (the Valley of the Noon), the Dead Sea, Akaba, Amman. For this reason, we performed the analysis of tourist destinations, tourist profiles, seasonal tourist traffic to such sites, accommodation and income from tourism and employment in the sector of services. The purpose of the paper was to analyze the Jordanian tourism market compared to other countries in the Middle East and prospects for its further development.
\end{abstract}


Słowa kluczowe: atrakcje turystyczne; destynacje; usługi turystyczne; zatrudnienie

Keywords: destinations; employment; tourist attractions; travel services

Otrzymano: 20 grudnia 2014

Received: 20 December 2014

Zaakceptowano: 13 lipca 2015

Accepted: 13 July 2015

\section{Sugerowana cytacja / Suggested citation:}

Wójtowicz, B., Wójtowicz, P. (2015). Atrakcje turystyczne Jordanii i ich znaczenie dla rozwoju usług turystycznych. Prace Komisji Geografii Przemystu Polskiego Towarzystwa Geograficznego, 29(3), $48-66$.

\section{WSTĘP}

Wśród różnorodnych uwarunkowań rozwoju współczesnej turystyki istotną rolę odgrywają walory turystyczne, które są jednym z ważniejszych elementów składowych systemu turystyki. Rola walorów turystycznych i ich wpływ na rozwój ruchu turystycznego są niepodważalne. $\mathrm{Z}$ jednej strony stanowią one jeden z głównych elementów systemu turystyki (Gunn, 1972), a z drugiej - o wyborze kierunku wyjazdu wypoczynkowego decyduje w znacznym stopniu atrakcyjność turystyczna obszaru, utożsamiana w polskiej literaturze przedmiotu z rangą walorów turystycznych, dostępnością komunikacyjną i zagospodarowaniem turystycznym (Kurek, 2007). Turystyka stała się jednym z najważniejszych działów globalnej gospodarki (Ferreira, Rial, Varela, 2009). Usługi turystyczne rozwijają się bardzo dynamicznie. Ich rozwój następuje na skutek wzrostu zamożności społeczeństw, zwiększania się ilości czasu wolnego, a także rozwoju komunikacji. Jednym z najlepiej zagospodarowanych i najczęściej odwiedzanych przez turystów krajów Bliskiego Wschodu jest Jordania. Obok Arabii Saudyjskiej, Egiptu i Emiratów Arabskich stanowi ona jeden z najważniejszych celów podróży na Bliski Wschód. Duże znaczenie ma dobrze rozwinięta infrastruktura turystyczna, bogata oferta aktywnego wypoczynku oraz otwartość społeczności lokalnych. Jednak nieustabilizowana sytuacja polityczna w regionie sprawia, że kraj ten jest niedoceniany turystycznie.

$\mathrm{Z}$ uwagi na rosnącą rolę Jordanii w światowej turystyce w niniejszym artykule przedstawiono największe jego walory turystyczne oraz dokonano analizy rynku usług turystycznych.

\section{PROBLEMATYKA I OBSZAR BADAŃ}

Walory przyrodnicze Jordanii stanowią o potencjale rozwoju gospodarki turystycznej tego państwa. Jordania to kraj o zróżnicowanej pod względem morfologicznym powierzchni wynoszącej $89206 \mathrm{~km}^{2}$ i populacji ok. 6,4 mln mieszkańców, w którym znajduje się jeden z najniżej położonych na świecie obszarów - depresja Morza Martwego (392 m p.p.m.), a najwyższe wzniesienia leżą na południu kraju - Jabal Rum (1754 m n.p.m.) na pustyni Wadi Rum. Według UNTWO Tourism Highilghts, 2014 edition, Jordanię odwiedziło w 2013 roku 
3,585 mln turystów, głównie z Bliskiego Wschodu, USA oraz krajów europejskich. Przyczyną niewielkiego spadku, (w porównaniu z rokiem 2012) były najprawdopodobniej zamieszki na tle religijnym trwające w regionie. Spadek odnotowano przede wszystkim wśród turystów pochodzących z krajów europejskich, a także z Bliskiego Wschodu, głównie Syrii i Iraku. Ponieważ o potencjale rozwoju gospodarki turystycznej Jordanii stanowią walory turystyczne, w artykule przedstawiono najatrakcyjniejsze z nich, jak: Petra, Pustynia Wadi Rum, Morze Martwe, Akaba, Amman na tle destynacji turystycznej i infrastruktury turystycznej.

\section{ATRAKCJE TURYSTYCZNE JORDANII}

Pojęcie atrakcji turystycznych jest różnie definiowane w literaturze. Jedni autorzy za atrakcje turystyczne uważają walory turystyczne występujące w stanie naturalnym lub przystosowane do użytkowania przez turystów, które mogą stanowić przedmiot ich zainteresowania (Lijewski, Mikułowski, Wyrzykowski, 2002). Z kolei Z. Kruczek i S. Sacha (1995) uznają za atrakcję turystyczną walor turystyczny wzbogacony o jego promocję. S. Medlik (1995), zgodnie z terminologią brytyjską, utożsamia walory i atrakcje turystyczne ze składnikami produktu turystycznego, które przyciągają odwiedzających i decydują o tym, że wybierają oni dany obszar, a nie inny. Podobnie uważa M. Nowacki (2002), uznając, że zarówno walor, jak i atrakcje turystyczne są cechami lub elementami środowiska, które wywołują zainteresowanie wśród turystów i oni decydują o wyborze podróży. Walory turystyczne zdaniem J. Warszyńskiej i A. Jackowskiego (1978) to zespół elementów środowiska naturalnego oraz elementów pozaprzyrodniczych, które - wspólnie lub każde z osobna - są przedmiotem zainteresowania turysty. Zbliżone znaczeniowo definicje można również znaleźć w pracach O. Rogalewskiego (1979), A. Kowalczyka (2001), G. Gołembskiego (2002) i innych.

\section{Akaba - miasto portowe nad Morzem Czerwonym}

W X wieku p.n.e. Akaba była ośrodkiem wytopu miedzi i jednocześnie wioską rybacką. Dziś jest to miasto utrzymujące się głównie z turystyki. Turystów przyciąga do Akaby bardzo czyta woda, piaszczyste plaże oraz wysoka temperatura - w zimie jest tam $+25^{\circ} \mathrm{C}$, podczas gdy w stolicy tylko $+10^{\circ} \mathrm{C}$ (Warszyńska, 1994). Ponadto jest to interesujący obszar dla pasjonatów nurkowania, ponieważ w Morzu Czerwonym, nad którym leży Akaba, znajduje się blisko 150 gatunków koralowców. W związku z tym działa tam wiele szkół nurkowania. Można tu również jeździć na nartach wodnych oraz surfować. Dla turystów kładących nacisk na aspekt poznawczy ważnym zabytkiem jest fort mameluków, pierwotnie zamek krzyżowców, który został przebudowany w XVI wieku (Mayhew, 2006). Do dzisiaj zachował się ciąg murów obronnych wzdłuż dziedzińca, kilka pustych pomieszczeń, narożne baszty i portal wejściowy w bramie głównej. Atrakcję turystyczną stanowi niewielkie Muzeum Archeologiczne, urządzone w dawnym domu przywódcy powstania antytureckiego - szarifa Husajna. Znajdują się w nim znaleziska związane z tajemniczym ludem Nabatejczyków. W mieście zobaczyć można także pozostałości po kościele bizantyjskim z IV wieku. Interesującym obiektem jest Centrum Nauk Morskich z akwarium prezentującym bogactwo czerwonomorskiej flory i fauny. 


\section{Pustynia Wadi Rum}

Pustynia Wadi Rum to jedna z największych atrakcji turystycznych Jordanii. Jest jeszcze mało znana wśród turystów, chociaż coraz częściej odwiedzana, zwłaszcza przez turystów zagranicznych udających się z południa na północ do największego zabytku kultury światowego dziedzictwa kulturowego UNESCO - miasta Nabatejczyków Petry. Położona na styku Afryki i Azji, w strefie sejsmicznej Morza Czerwonego, na południu Jordanii, w odległości ok. 70 km od Zatoki Akaba, pustynia Wadi Rum jest rezerwatem przyrody ożywionej i nieożywionej. Z punktu widzenia budowy geologicznej Wadi Rum obejmuje wielki płaskowyż zbudowany z ordowickich piaskowców, który wskutek intensywnej erozji rozpadł się na wydłużone masywy i ostańce skalne, opadające ścianami skalnymi na dno płaskich, rozdzielających je dolin. Efektem tego procesu są też różnobarwne piaski tworzące liczne wydmy. Obszar Wadi Rum jest interesujący krajobrazowo i geologicznie - od płaskiej piaszczystej pustyni pokrytej kolorowymi piaskami do wysokich gór. Teren ten leży na wysokości 900-1000 m n.p.m., a potężne skaliste szczyty sięgają tu z reguły kilkuset metrów. Najwyższe masywy górskie, jak Jabal Rum (1754 m n.p.m.), Jabal Um Ishrin (1753 m n.p.m.), Jabal Kharaz i Jabal Burdah, górują nad całym terenem. Są zarazem wielką atrakcją tego miejsca. Stanowią one formację piaskowca Dubaydib (Makhlouf, 1998), znaną wcześniej jako piaskowiec Sabellarifex (Bender, 1974), obejmujący ordowickie osady: jasnobrązowe, drobnoziarniste, łyszczykowe arenity kwarcowe, które zmieniają się od utworów masywnych do piaskowców o warstwowaniu krzyżowym. Interesujące są czerwone wydmy piaszczyste Um Ishrin (fot. 1) sąsiadujące z wyniosłym masywem Jebel Um Ishrin.

Fot. 1. Czerwone wydmy Um Ishrin

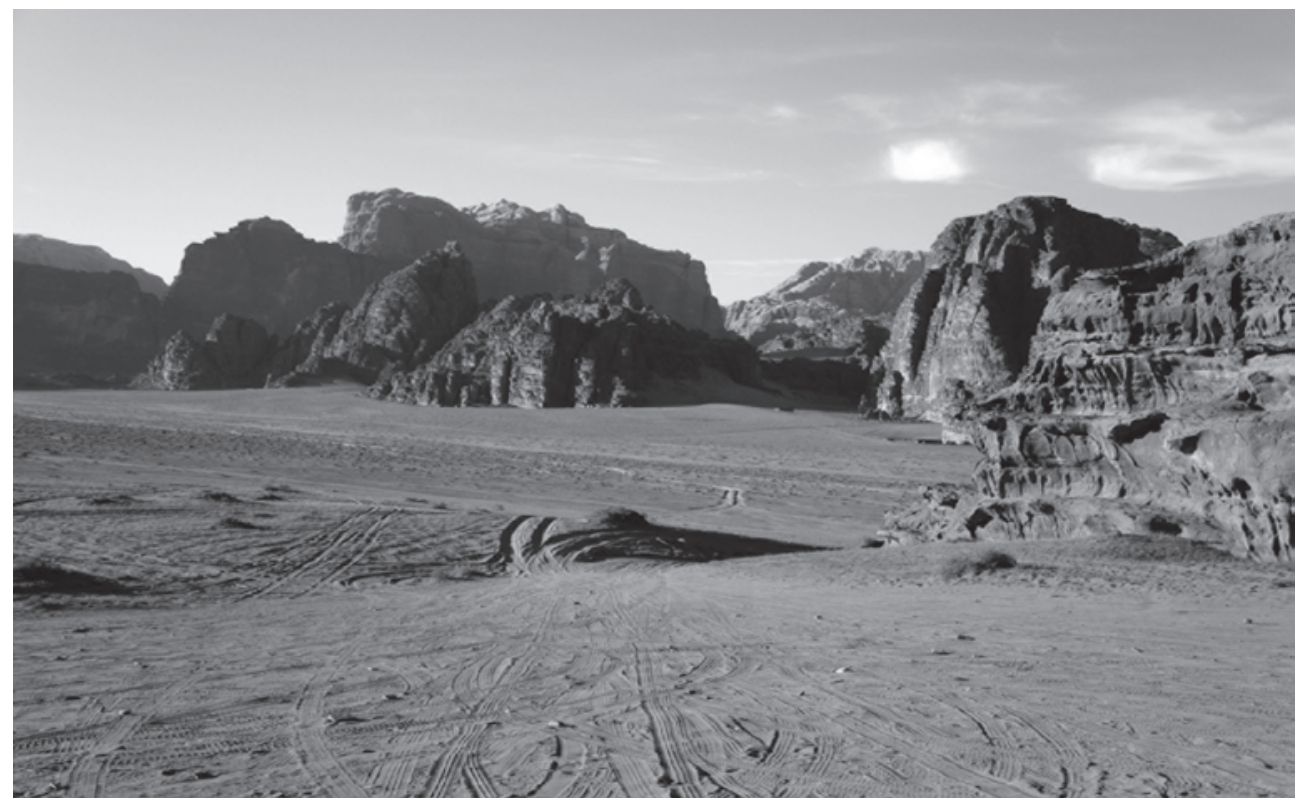

Źródło: fot. Paweł Wójtowicz, 2013 
Fot. 2. Most powstały na skutek wietrzenia na pustyni Wadi Rum

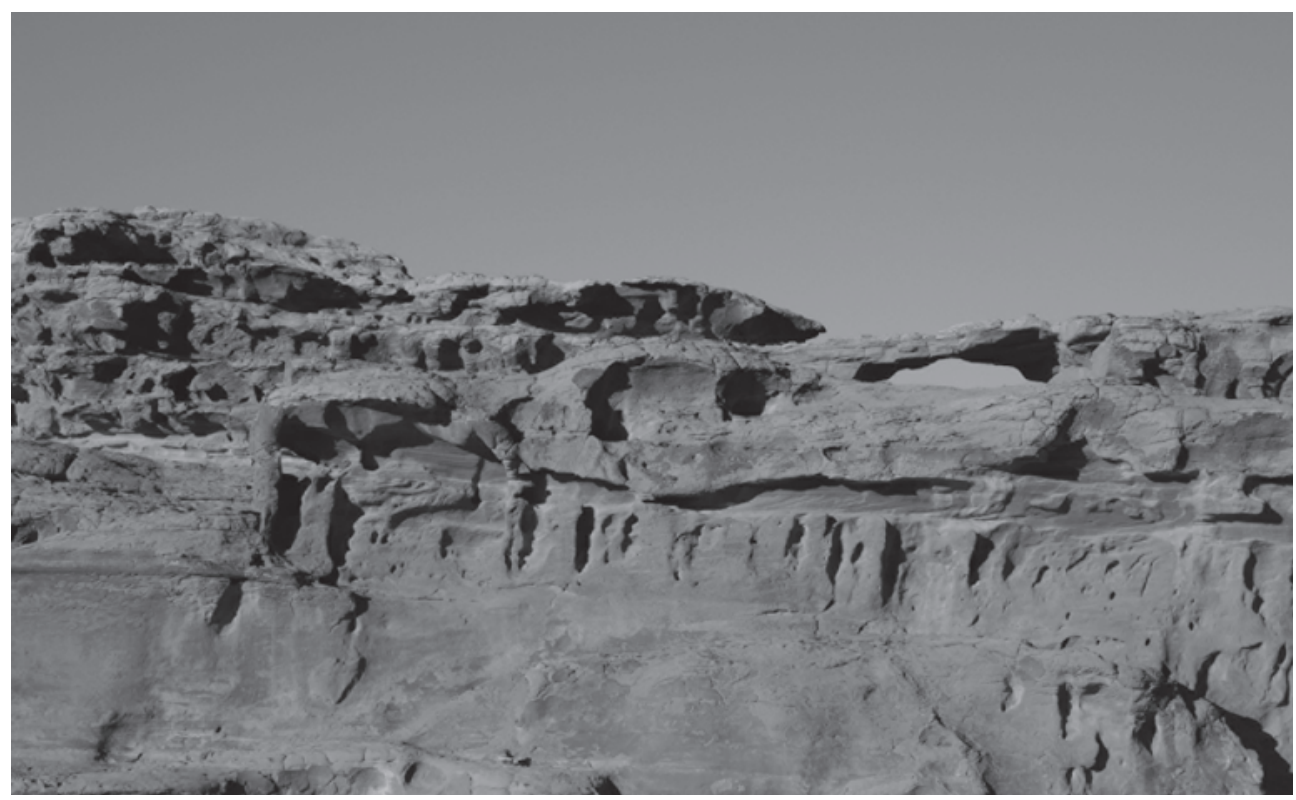

Źródło: fot. Paweł Wójtowicz, 2013

Fot. 3. Masyw skalny - Siedem Filarów Mądrości

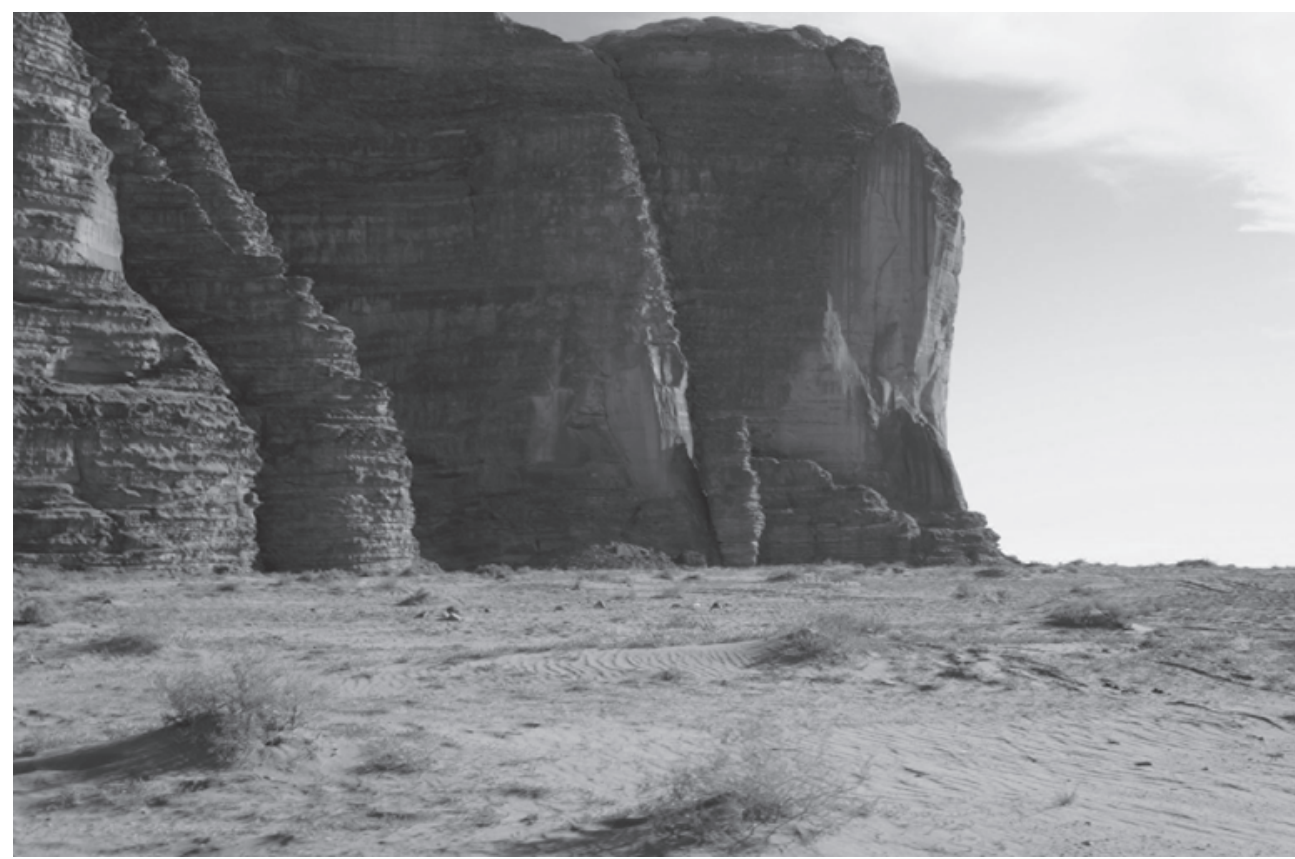

Źródło: fot. Paweł Wójtowicz, 2013 
Formy wietrzeniowe piaskowców to pojedyncze ostańce, charakterystyczne mosty skalne (np. Burdah czy Um Frouth), kaniony wypełnione piaskiem czy potężne masywy (fot. 2, 3). Na niektórych skałach zobaczyć można graffiti, prawdopodobnie dzieło Nabatejczyków, na pustyni zachowały się również pozostałości ich świątyni).

Wadi Rum, zwana również Doliną Księżycową, zajmuje niewielki obszar - zaledwie $720 \mathrm{~km}^{2}$. Została wpisana na listę światowego dziedzictwa UNESCO. Rząd Jordanii dba o ochronę środowiska przyrodniczego, ponieważ na pustyni mają prawo pracować i mieszkać tylko Beduini, a cały obszar jest ściśle chroniony.

\section{Miasto Petra - wykute w skale}

Miasto wpisane zostało na listę światowego dziedzictwa UNESCO. W języku greckim „petra” oznacza „skałę”. Petra została wykuta przez Nabatejczyków w III-II wieku p.n.e. Pierwszą rzeczą przykuwającą uwagę w drodze do miasta jest przejście przez wąwóz As-Sik, długi na ponad kilometr i otoczony skalnymi ścianami wysokimi na $80 \mathrm{~m}$. Na końcu wąwozu znajduje się najbardziej imponująca budowla Petry, zwana skarbcem Al-Chazna, wykuta w skale z początkiem I wieku (fot. 4). Większa część budynków Petry została zniszczona w wyniku trzęsienia ziemi, ale do dzisiaj zachowało się 500 bardzo cennych grobowców. Petra to przykład niezwykłej kultury, bogatej architektury i wyrafinowanego stylu życia. Miasto przez wieki zapomniane, pilnie strzeżone przez Beduinów, zostało na nowo odkryte w 1812 roku przez szwajcarskiego podróżnika. Znajdują się tu wykute w skałach, wspaniale zachowane świątynie, domy, grobowce, pomniki, mozaiki, akwedukty wodne i fontanny (fot. 5). Amfiteatr wybudowany na 8 tys. osób budzi podziw wśród turystów. Interesującym obiektem jest również wykuty w skale klasztor (Encyklopedia geograficzna świata. Azja, 1998).

Fot. 4. Skarbiec w Petrze

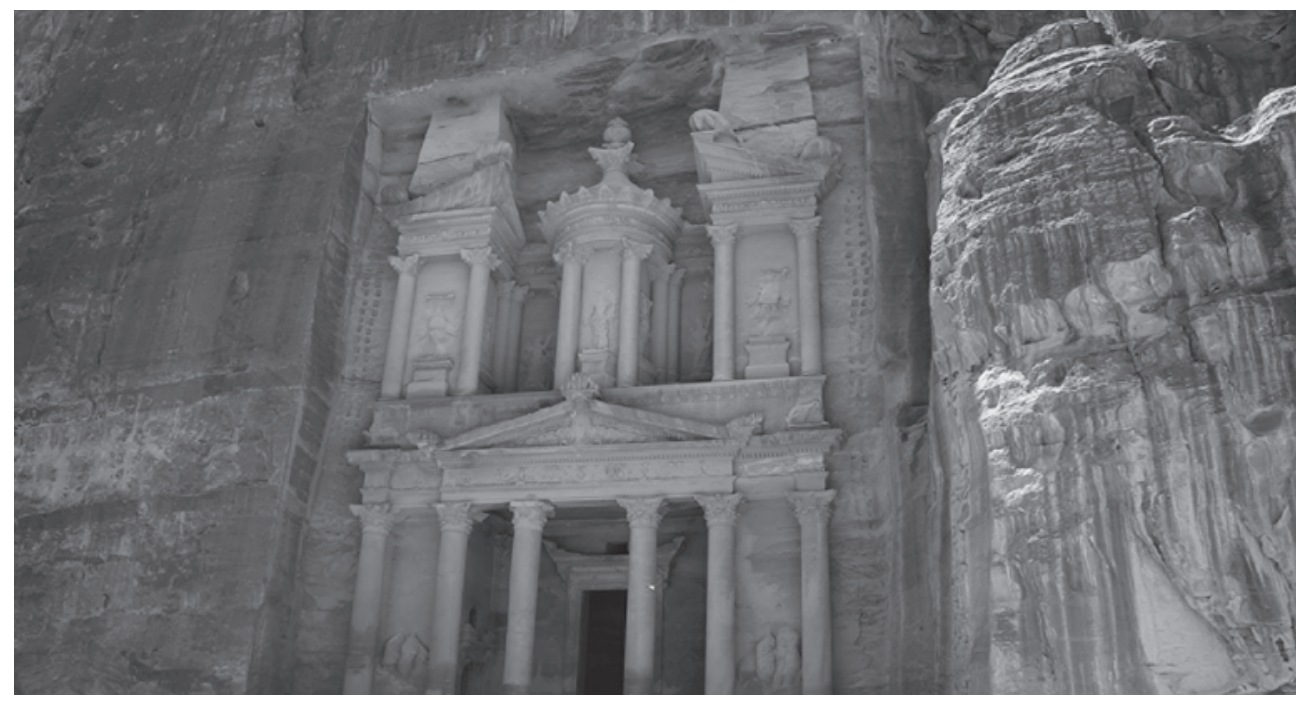

Źródło: fot. Paweł Wójtowicz, 2013 
Fot. 5. Miasto Petra

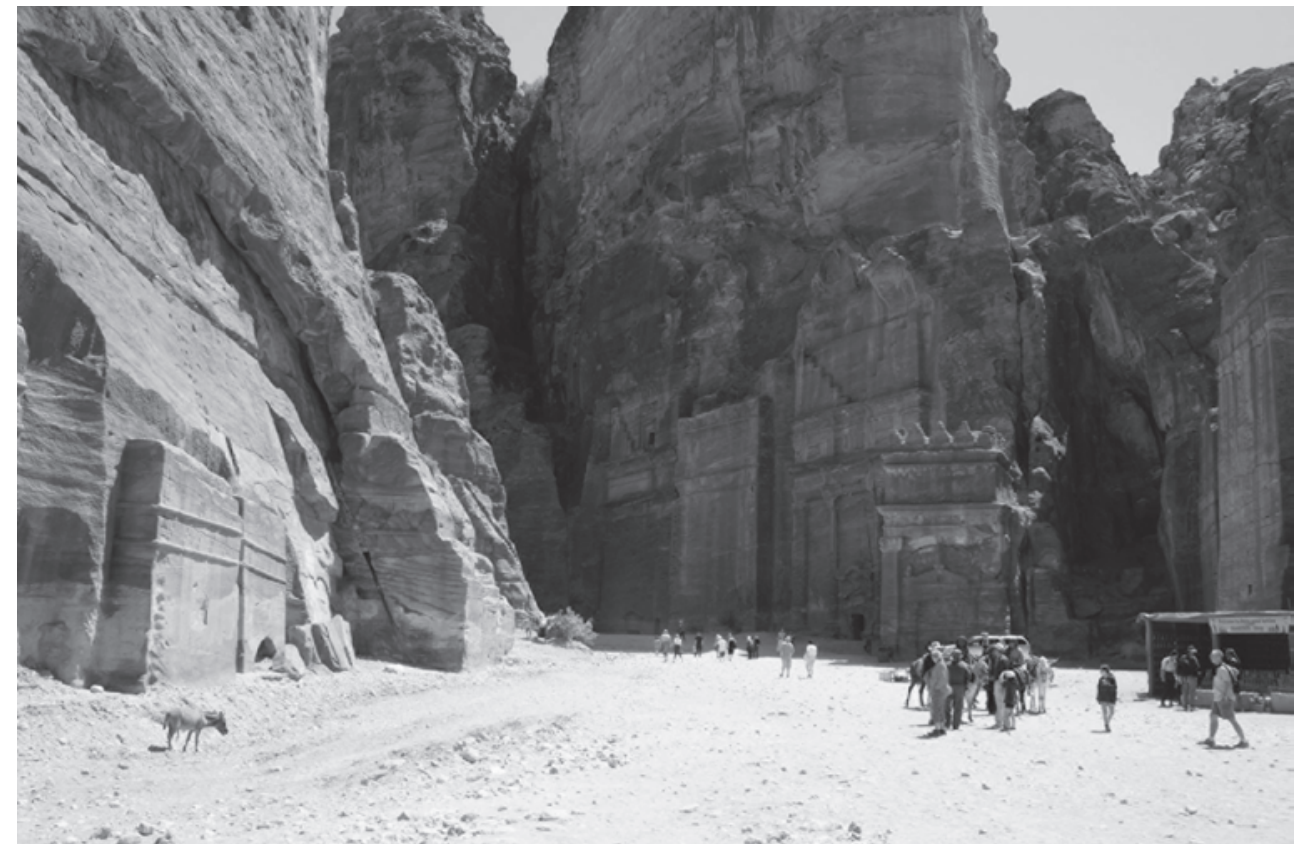

Źródło: fot. Paweł Wójtowicz, 2013

\section{Morze Martwe}

Będące w zasadzie jeziorem, Morze Martwe jest położone w rowie rzeki Jordan. Jego wody mają bardzo wysokie stężenie soli. W pobliżu tego zbiornika mieści się wiele ośrodków spa oraz uzdrowisk, w których wykonywane są np. zabiegi z błota, wykorzystujące naturalne właściwości środowiska Morza Martwego. Dzięki dogodnemu położeniu i czystemu powietrzu, zawierającemu więcej tlenu niż powietrze w pozostałych częściach kraju, rozwija się tam turystyka zdrowotna. Gorące źródła znajdujące się w okolicy pomagają w leczeniu chorób skóry i stawów.

\section{Amman - stolica kraju}

To najbardziej zaludnione miasto Jordanii. Główne zabytki Ammanu warte obejrzenia to m.in. rzymski amfiteatr, który mógłby pomieścić 5 tys. widzów, forum oraz kolumnada. Na północy znajduje się rzymska cytadela, z której rozpościera się piękny widok na stolicę. Ponadto godne zwiedzenia jest śródmieście Ammanu, gdzie znajduje się znany targ, dużo restauracji, obiektów świadczących usługi noclegowe oraz większość atrakcji turystycznych. Ze stolicy do Akaby prowadzi autostrada, zwana królewską. Podróż tą długą na $335 \mathrm{~km}$ trasą jest bardzo ciekawa, ponieważ można obserwować przepiękne jordańskie krajobrazy oraz najważniejsze zabytki. 


\section{ROZWÓJ USŁUG TURYSTYCZNYCH W JORDANII}

Jordania zajmuje czołowe miejsce wśród krajów Bliskiego Wschodu, jeśli chodzi o odwiedzających ją turystów, nie tylko ze względu na walory turystyczne, ale również z powodu dynamicznego rozwoju usług turystycznych (Meyer, 2010). Potencjał turystyczny to szerokie pojęcie obejmujące ogół elementów umożliwiających rozwój turystyki na danym obszarze. Wśród nich można wyróżnić elementy strukturalne, związane z czynnikami przestrzennymi oraz funkcjonalne, związane $\mathrm{z}$ działaniami podmiotów bezpośrednio i pośrednio zaangażowanych w działalność turystyczną (Meyer, 2010). Obie grupy elementów są niezbędne do rozwoju turystyki i ich łączne występowanie może się do niego przyczyniać. Wydaje się jednak, że podstawowe znaczenie mają elementy strukturalne, obejmujące walory turystyczne oraz zagospodarowanie turystyczne obszaru, stanowiące podstawę do wykreowania regionu jako atrakcyjnego turystycznie. Jednakże bazą dla działań podejmowanych przez zróżnicowane podmioty zaangażowane w rozwój turystyki w regionie pozostają elementy strukturalne. Wśród nich wyróżniają się czynniki o charakterze przestrzennym, związane z walorami turystycznymi różnego typu i ich zagospodarowaniem, oraz infrastrukturalne, umożliwiające potencjalnym turystom dotarcie do regionu i satysfakcjonujące spędzenie czasu wolnego (Mayhew, 2006).

Infrastrukturę turystyczną Jordanii tworzy sieć hoteli na terenie całego kraju (519 hoteli sklasyfikowanych), z których najwięcej znajduje się w Ammanie (65\%). Wśród sieci hotelarskiej najliczniejszą grupę stanowią tzw. niesklasyfikowane hotele, apartamenty $\mathrm{C}$ oraz hotele trzy-, dwu- i jednogwiazdkowe. W ostatnich latach można zauważyć większe zainteresowanie tym krajem znanych sieci hotelowych o wysokim standardzie, takich jak: Hilton, Marriott, Le Meridien, Days Inn, Radisson Sas, Golden Tulip. Ich aktywność wzrosła po wpisaniu Petry na listę światowego dziedzictwa kulturowego UNESCO i uznaniu jej za jeden z siedmiu nowych cudów świata. Analizując dane statystyczne dotyczące liczby hoteli i ich rodzajów oraz zatrudnienia w sektorze usług hotelarskich, widzimy wyraźny wzrost w ostatnich latach w porównaniu z okresem wcześniejszym (lata 2009-2013). Liczba hoteli $\mathrm{z}$ roku na rok stale się zwiększa (ryc. 1). Więcej jest też apartamentów - z $3983 \mathrm{w}$ roku 2010 do 4628 w roku 2013. Wzrosła także liczba pokoi, których w 2009 roku było 22880 , do $26370 \mathrm{w}$ roku 2013.

Oprócz usług hotelarskich powstawały szybko także nowe biura podróży, których w roku 2013 było 806, wzrost nastąpił także w usługach przewodnickich, w roku 2013 było ich 1200. Niewielki wzrost w usługach turystycznych odnotowano w powstaniu tzw. sklepów orientalnych z antykami - z 309 w 2009 roku do 368 w 2013 roku (tab. 1). Najmniej dynamicznie rozwijały się firmy transportowo-przewozowe, wzrost o jeden w stosunku do 2009 roku (w 2013 roku działało ich osiem, a w 2009 - siedem). Nie zmieniła się liczba ośrodków jazdy z wykorzystaniem zwierząt (jazda konna, jazda na wielbłądach), których w latach 2009-2013 działało 713. Dynamiczny rozwój usług turystycznych ma również miejsce w gastronomii, w 2013 roku działały 963 restauracje, to o prawie 200 więcej niż w 2009 roku. 
Ryc. 1. Liczba hoteli w Jordanii

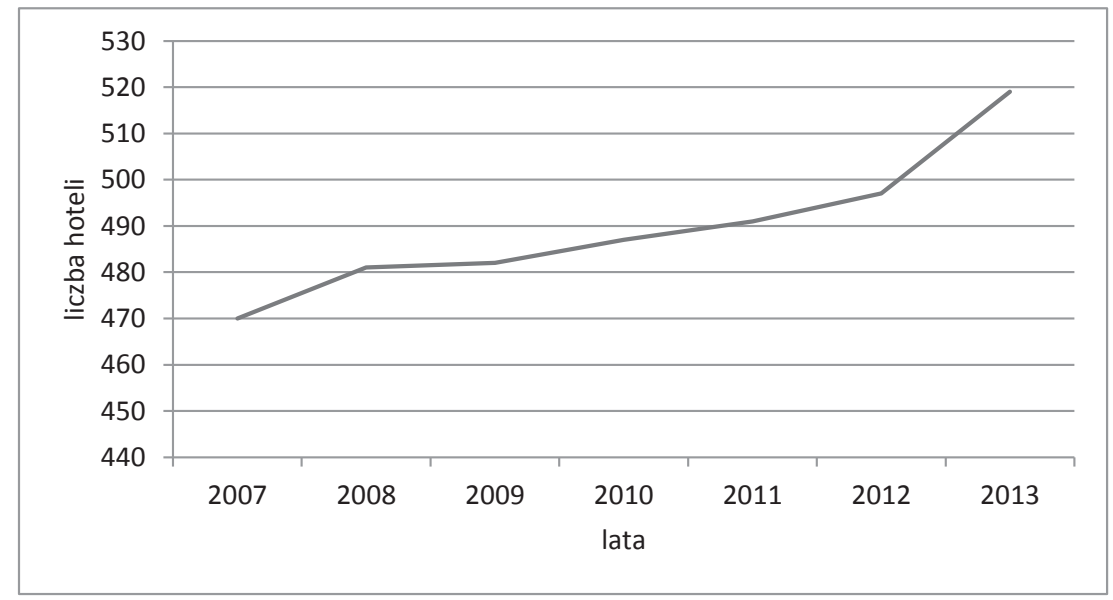

Źródło: opracowanie własne na podstawie danych Ministerstwa Turystyki Jordanii, 2014

Tab. 1. Rozwój usług turystycznych w Jordanii

\begin{tabular}{|l|r|r|r|r|r|}
\hline \multirow{2}{*}{\multicolumn{1}{|c|}{ Rodzaje usług }} & \multicolumn{5}{c|}{ Lata } \\
\cline { 2 - 7 } & 2009 & \multicolumn{1}{c|}{2010} & 2011 & 2012 & \multicolumn{1}{c|}{2013} \\
\hline liczba pokoi & 22880 & 24009 & 24147 & 24703 & 26370 \\
\hline liczba apartamentów & - & 3983 & 4050 & 4280 & 4628 \\
\hline liczba łóżek & 44300 & 46141 & 46425 & 47339 & 50142 \\
\hline biura podróży & 651 & 727 & 799 & 798 & 806 \\
\hline ośrodki jazdy (konie, wielbłądy) & 713 & 713 & 713 & 713 & 713 \\
\hline sklepy orientalne z antykami & 309 & 304 & 316 & 451 & 368 \\
\hline przewodnicy & 855 & 988 & 1140 & 1181 & 1200 \\
\hline firmy transportowe przewożące turystów & 7 & 8 & 8 & 8 & 8 \\
\hline restauracje turystyczne & 773 & 802 & 799 & 907 & 963 \\
\hline
\end{tabular}

Źródło: opracowanie własne na podstawie danych Ministerstwa Turystyki Jordanii, 2014

Nastąpił również szybki wzrost zatrudnienia w sektorze usług turystycznych. O rozwoju usług turystycznych świadczyć może dynamika zatrudnienia w poszczególnych segmentach tego sektora. Największy wzrost zatrudnienia odnotowano w 2010 roku, w którym przyjechało do Jordanii najwięcej turystów.

Największą dynamikę wzrostu obserwujemy w zatrudnieniu w usługach gastronomicznych, głównie w restauracjach, w których w 2013 roku pracowało 19512 osób, o blisko 3 tys. więcej niż w 2009 roku (16 425 pracowników). Wzrost zatrudnienia nastąpił również w biurach i agencjach turystycznych, w których w 2013 roku pracowało przeszło 800 osób więcej (4783) niż w roku 2009 (3975), przy czym najwięcej pracowników, bo ok. 400, przybyło w 2010 roku (w porównaniu z rokiem 
poprzednim). Na trzecim miejscu plasuje się zatrudnienie w przedsiębiorstwach wynajmujących samochody. W 2013 roku pracowało tam 1476 osób, chociaż w tym sektorze usług obserwujemy spadek w stosunku do 2009 roku o blisko 282 osoby. Wzrost zatrudnienia nastąpił w usługach przewodnickich, gdzie w 2013 roku pracowało 1200 osób, czyli o 345 więcej niż w 2009 roku (855 osób).

Najmniejszy wzrost zatrudnienia w usługach turystycznych Jordanii w 2013 roku nastąpił w sektorze handlu, w tzw. orientalnych sklepach z antykami, bo tylko o 146 osób w stosunku do 2009 roku. Na niezmiennym poziomie w latach 20092013 pozostaje zatrudnienie wśród instruktorów jeździectwa (jazda konna, jazda na wielbłądach), które wynosi 713 osób (tab. 2).

$T a b .2$. Zatrudnienie w usługach turystycznych w Jordanii

\begin{tabular}{|l|r|r|c|r|r|}
\hline \multirow{2}{*}{ Rodzaje usług } & \multicolumn{5}{c|}{ Lata } \\
\cline { 2 - 6 } & \multicolumn{1}{|c|}{2009} & 2010 & 2011 & 2012 & \multicolumn{1}{c|}{2013} \\
\hline agencje i biura podróży & 3975 & 4351 & 4582 & 4719 & 4783 \\
\hline firmy wynajmujące samochody & 1758 & 1520 & 1489 & 1489 & 1476 \\
\hline orientalne sklepy z antykami & 791 & 791 & 814 & 870 & 940 \\
\hline przewodnicy turystyczni & 855 & 988 & 1140 & 1181 & 1200 \\
\hline opiekunowie zwierząt (wielbłądy, konie) & 713 & 713 & 713 & 713 & 713 \\
\hline firmy transportowe turystyczne & 881 & 939 & 939 & 939 & 1047 \\
\hline restauracje turystyczne & 16428 & 17345 & 16855 & 18439 & 19512 \\
\hline
\end{tabular}

Źródło: opracowanie własne na podstawie danych Ministerstwa Turystyki Jordanii, 2014

\section{DestynaCJE RUCHU TURYSTYCZNEGO JORDANII}

Liczba turystów, którzy odwiedzili Jordanię w 2013 roku, wynosi 3,945 mln spośród 51,571 mln turystów odwiedzających Bliski Wschód. Pod względem osób przyjeżdżających na Bliski Wschód w 2013 roku Jordania plasuje się na czwartym miejscu po Arabii Saudyjskiej (13,213 mln), Emiratach Arabskich (9,99 mln) i Egipcie (9,174 mln turystów) (UNTWO Tourism Highlights, 2014). Analizując dynamikę przyjazdów zagranicznych do krajów Bliskiego Wschodu, widzimy wyraźny spadek liczby turystów w 2013 roku w porównaniu z 2010 (ryc. 2). Niestety, nieuwzględnione zostały przez UNTWO dane z krajów będących w stanie wojny, takich jak Syria i Irak (Syrię w 2010 roku odwiedziło 8,546 mln turystów, a w 2011 blisko 5,07 mln, a więc znacznie więcej niż Jordanię).

Przyczyny zmian w ruchu turystycznym to trwające w krajach sąsiadujących z Jordanią konflikty zbrojne. Jordania odnotowuje stały wzrost turystów zagranicznych od 2007 roku. W latach 2009-2010 liczba turystów odwiedzających to państwo wzrosła do 4,2 mln. W roku 2011 nastąpił niewielki spadek do 3,96 mln odwiedzających, by w 2012 roku ponownie wzrosnąć do 4,162 mln osób. W 2013 roku do Jordanii przybyło 3,945 mln turystów, o 217 tys. osób mniej niż w roku poprzednim. Przy analizie ruchu turystycznego należy 
zwrócić uwagę na istotną kwestię terminologiczną. Za UNTWO przyjmuje się definicję turysty jako osoby odwiedzającej, której przyjazd trwa przynajmniej jedną noc i której główny cel przyjazdu można zakwalifikować do jednej z następujących grup: czas wolny i wakacje, interesy i sprawy zawodowe, inne cele turystyczne (Medlik, 1995: 241). Natomiast „odwiedzający jednodniowy to osoba, której odwiedziny trwają mniej niż 24 godziny i nie obejmują noclegu" (Medlik, 1995: 212). Stąd według raportów jordańskiego Ministerstwa Turystyki (2014) do Jordanii w 2013 roku przyjechało 5,4 mln turystów, podczas gdy rok wcześniej było ich prawie milion więcej - 6,3 mln, w tym 672 tys. Europejczyków. Dynamika odwiedzających Jordanię turystów w 2013 roku wyniosła 85,7\% stanu z roku poprzedniego. Szczególnie duży spadek liczby turystów odnotowano przy pobytach krótkotrwałych. Turystów, którzy skorzystali z jednego noclegu, było mniej - z 4,2 $\mathrm{mln}$ do 3,5 $\mathrm{mln}$.

Ryc. 2. Przyjazdy turystów do krajów Bliskiego Wschodu ze szczególnym uwzględnieniem Jordanii

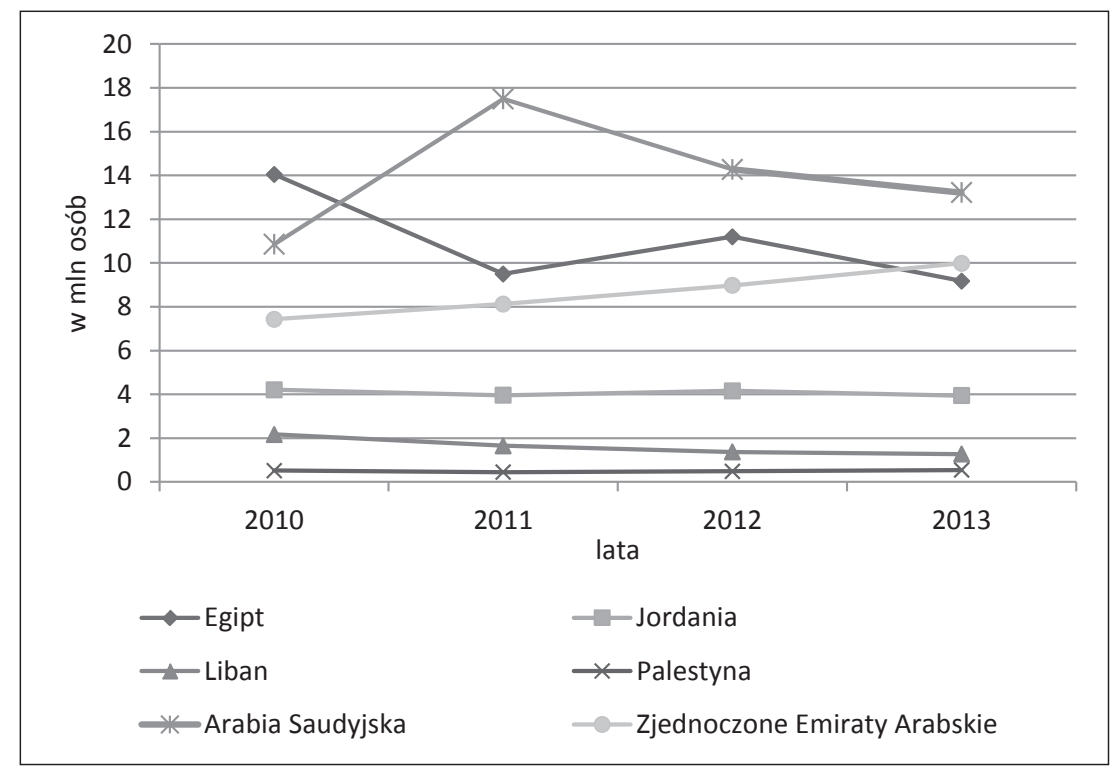

Źródło: opracowanie własne na podstawie danych UNWTO Highlights (2010, 2011, 2012, 2013, 2014)

\section{GŁÓWNE KRAJE EMISYJNE}

Według UNWTO Jordanię odwiedziło najwięcej turystów z krajów Bliskiego Wschodu: Arabii Saudyjskiej (582 037), Palestyny (367 574), Iraku (367 476), Syrii (316 303) oraz Izraela (162 789). Podróże do Jordanii z krajów Bliskiego Wschodu związane są głównie z religią. Celem turystyki religijnej jest miasto Petra wybudowane przez plemię Nabatejczyków. Najwięcej turystów spoza Bliskiego Wschodu stanowią Amerykanie (174 571), którzy odwiedzają region ze względu na jego dziedzictwo kulturowe oraz ofertę turystyki i rekreacji szczególnie dobrze rozwiniętej na południu kraju. Z Ameryki Północnej do Jordanii 
przyjeżdżają również Kanadyjczycy (32 443). Najliczniejszą grupę turystów z Ameryki Południowej stanowią Brazylijczycy (12 984), z Europy przybywają głównie Brytyjczycy (89 339), Niemcy (69 742) i Rosjanie (50 484). Zarówno Amerykanie, jak i Europejczycy uprawiają głównie turystykę poznawczą i rekreację oraz turystykę estetyczną, zwłaszcza nad Morzem Martwym. W 2013 roku turystów z Polski było 12 993. Odwiedzili oni Jordanię w ramach turystyki poznawczej i/lub turystyki religijnej.

Azjatyccy turyści w Jordanii pochodzili najczęściej z takich państw, jak: Indie (68 591 osób), Indonezja (45 994 osoby), Filipiny (31 897 osób) i Malezja (29 152 osoby). Z krajów Afryki na czele odwiedzających znajdowała się Etiopia - 7521 turystów i Nigeria - 2281 turystów (UNWTO, 2014). Jordanię odwiedzili również turyści z odległej Australii (25 386) i Nowej Zelandii (4411). Poniższy wykres przedstawia liczbę turystów odwiedzających Jordanię wg regionów i krajów o największej liczbie przyjazdów w 2013 roku (ryc. 3).

Ryc. 3. Kraje, z których przyjechało do Jordanii najwięcej turystów w 2013 roku

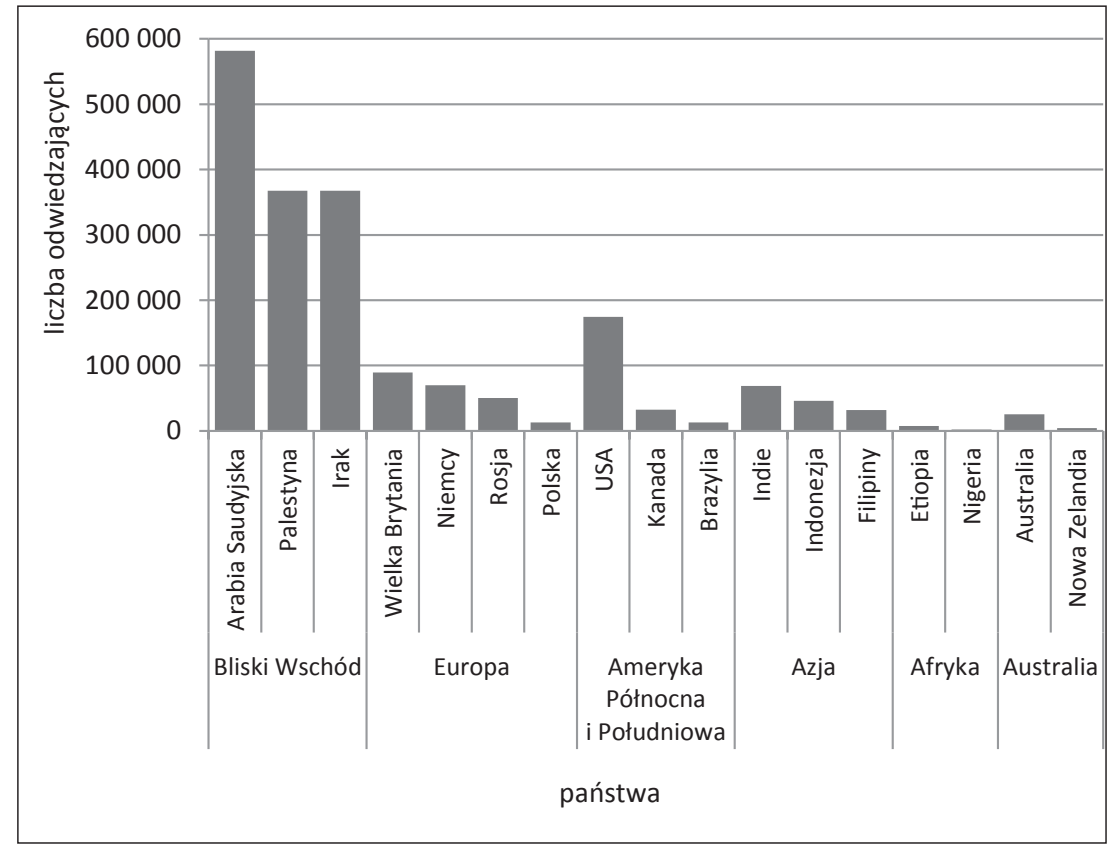

Źródło: opracowanie własne na podstawie danych pozyskanych z http://www.eunwto.org/doi/pdf/10.18111/ 9789284415427

\section{DOCHODY Z TURYSTYKI}

Dochody Jordanii z turystyki w 2013 roku wyniosły 3,47 mld dol., co stanowiło 7,4\% wszystkich dochodów z turystyki krajów Bliskiego Wschodu. Udział Jordanii w rynku turystycznym regionu stawia ją na czwartym miejscu za Zjednoczonymi Emiratami Arabskimi, 
Egiptem i Arabią Saudyjską. Należy jednak pamiętać, że takie kraje jak Syria i Irak miały większe dochody z turystyki, ale ze względu na trwające w nich konflikty zbrojne nie zostały objęte statystyką w 2013 roku (ryc. 4). Analizując dane dotyczące dochodów z turystyki przyjazdowej, można zauważyć, iż począwszy od 2009 roku następował ich stały wzrost, największy w 2010 r. - wynosiły wtedy 3,585 mld dol. W 2011 roku odnotowano niewielki spadek, zaś od 2013 roku obserwujemy ich ponowny wzrost. Branża turystyczna w 2013 roku wytwarzała 14\% PKB i zatrudniała bezpośrednio ponad 42 tysiące osób, a pośrednio ponad 130 tys.

Ryc. 4. Dynamika dochodów z turystyki przyjazdowej Jordanii w latach 2009-2013 (w mld dol.)

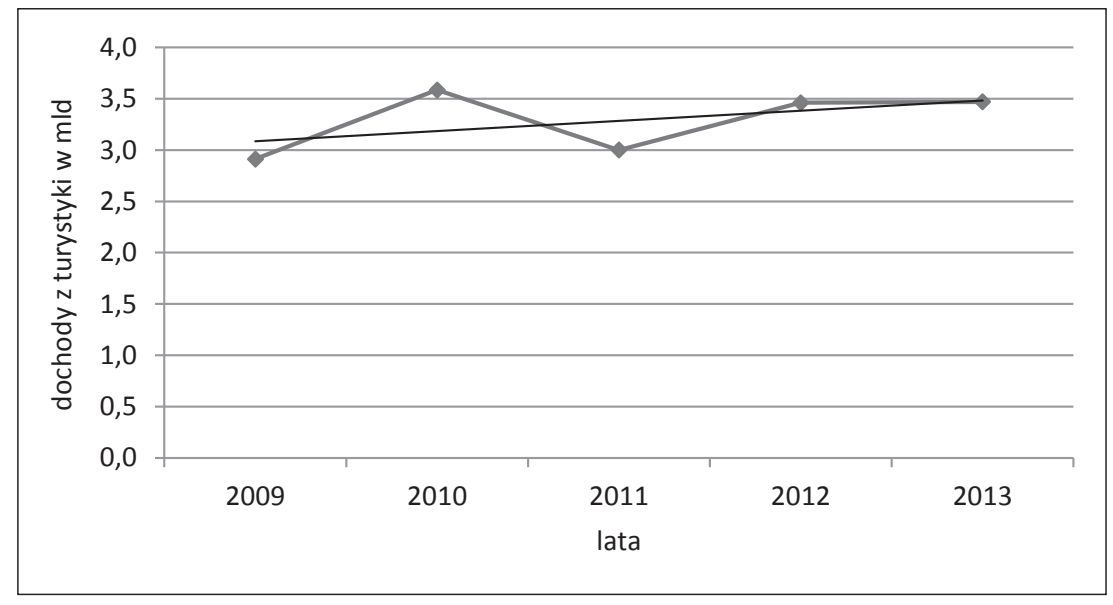

Źródło: opracowanie własne na podstawie danych UNWTO Highlights (2010, 2011, 2012, 2013)

\section{RYNEK RECEPCJI TURYSTYCZNEJ}

Gospodarka narodowa Jordanii w znacznym stopniu oparta jest na sektorze usług, którego udział w tworzeniu produktu krajowego brutto wynosi 72,9\%, czyli 33,68 mld dol. (2013). Spośród liczącej 6,459 mln ludności Jordanii z turystyką związanych jest prawie 3\% osób, ta gałąź gospodarki generuje zaś 14\% PKB. Prowadzenie działań mających zwiększyć ruch turystyczny jest więc ważnym elementem tamtejszej polityki, w którą włącza się rodzina królewska. Sektor usług turystycznych zaczął się bardzo dynamicznie rozwijać od początku lat dziewięćdziesiątych ubiegłego wieku, jednakże wybuch powstania palestyńskiego - Intifady Al-Aksa w 2000 roku, a następnie negatywne konsekwencje zamachów terrorystycznych z 11 września 2001 roku przyczyniły się do poważnej recesji branży turystycznej. Z drugiej strony, inne sektory zwiększyły swój udział w tworzeniu PKB dzięki dobrej koniunkturze w budownictwie oraz napływowi bezpośrednich inwestycji zagranicznych. Rok 2013, mimo niepokojów w regionie i mniejszej liczby zagranicznych gości, był dla branży turystycznej w Jordanii bardzo udany. Choć mniej było przyjazdów, turystyka 
przyniosła dochód w wysokości 3,47 mld dol., czyli o 15,35\% więcej niż w 2011 roku. Wzrosła też liczba jednodniowych turystów - o 5,1\%, do poziomu 4,2 mln osób (dane Ministerstwa Turystyki Jordańskiej z 2013 roku). Wzrost nastąpił również w rozwoju bazy noclegowej, z której w 2013 roku skorzystało o 18,1\% więcej turystów, a wskaźnik RevPAR (średni przychód z jednego pokoju) wzrósł o 30,4\%. Dzięki budowanym obiektom liczba pokoi wzrośnie o 3858, co ma się przełożyć na wyniki branży. Ponadto ukończone zostały prace nad zwiększeniem przepustowości portu lotniczego w Ammanie, która zwiększyła się do 9 mln pasażerów rocznie. Rozwój turystyki w Jordanii ilustruje realizowany w oparciu o kapitał saudyjski projekt kompleksu turystycznego Ayla Oasis w Akabie. Wartość całej inwestycji szacowana jest na 1,4 mld dol. Warto także zwrócić uwagę na specjalną strefę ekonomiczną w Akabie z dogodnymi regulacjami prawnymi (strefa funkcjonuje w ramach wolnego obszaru celnego - zwolnienia podatkowe, uproszczone procedury rejestracji firm). Ponadto, dzięki położeniu nad Morzem Czerwonym, u zbiegu granic czterech państw (Jordanii, Izraela, Egiptu i Arabii Saudyjskiej), Akaba cieszy się dużym zainteresowaniem inwestorów z krajów Zatoki Perskiej inwestujących w branżę hotelarską. Akaba jako miasto portowe i siedziba zarządu specjalnej strefy ekonomicznej jest drugim po Ammanie, najprężniej rozwijającym się ośrodkiem gospodarczym Jordanii. W Akabie rozpoczęto wiele projektów inwestycyjnych, których łączna wartość przekracza 7 mld dol.

\section{RYNEK RECEPCJI TURYSTYCZNEJ DO NAJWIĘKSZYCH ATRAKCJI TURYSTYCZNYCH JORDANII}

Najwięcej turystów, ponad 600 tys., odwiedza Petrę, zaliczaną do siedmiu nowych cudów świata. Z przedstawionych w niniejszym artykule atrakcji turystycznych kolejne miejsce zajmuje pustynia Wadi Rum. W 2013 roku przybyło do niej przeszło 123,8 tys. turystów, wśród których dominowali turyści zagraniczni (86,5\%). Miastem turystycznym jest również Akaba, którą odwiedza rocznie ponad pół miliona osób, głównie w celach wypoczynkowych i rekreacyjnych. Dużym zainteresowaniem cieszy się Muzeum Archeologiczne w Ammanie, w którym eksponowane są zabytki z całego obszaru Jordanii (Mayhew, 2006), w tym część zwojów z Qumran, zabytki z Petry i Jerycha. Najmniejszym zaś zainteresowaniem wśród turystów krajowych i zagranicznych wśród obiektów muzealnych i archeologicznych cieszy się muzeum w Akabie (ryc. 5).

Jeśli chodzi o infrastrukturę turystyczną w wybranych obiektach, to najlepiej jest ona rozwinięta w stolicy kraju, Ammanie, w którym znajduje się 129 hoteli o najwyższym poziomie obsługi, grupa tzw. niesklasyfikowanych hoteli, apartamentów C (1023 jednostki) oraz hotele trzy-, dwu- i jednogwiazdkowe. Zatrudnionych w usługach hotelarskich w Ammanie było w 2013 roku 8647 pracowników. Bardzo dobrze rozwiniętą sieć hotelarską posiada Akaba, w której znajduje się 41 hoteli i 68 apartamentów, a zatrudnionych w usługach hotelarskich jest 2660 osób. Dynamiczny rozwój usług hotelarskich nastąpił również w ostatnich latach w Petrze, która posiada 26 sklasyfikowanych hoteli o wysokim standardzie oraz 83 apartamenty, a zatrudnionych jest w nich 1116 osób (ryc. 6). 
Ryc. 5. Liczba odwiedzających wybrane obiekty turystyczne Jordanii w latach 2012-2013

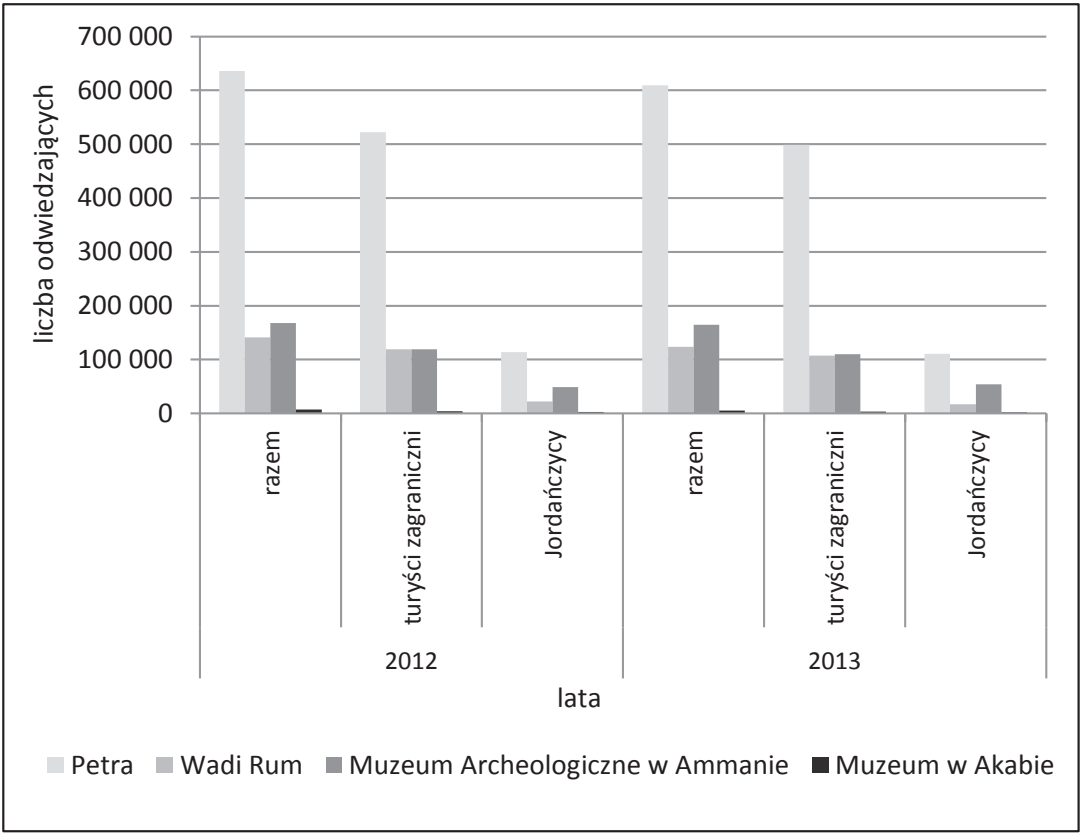

Źródło: opracowanie własne na podstawie danych Ministerstwa Turystyki Jordanii, 2014

Ryc. 6. Elementy bazy turystycznej w wybranych miastach Jordanii w 2013 roku

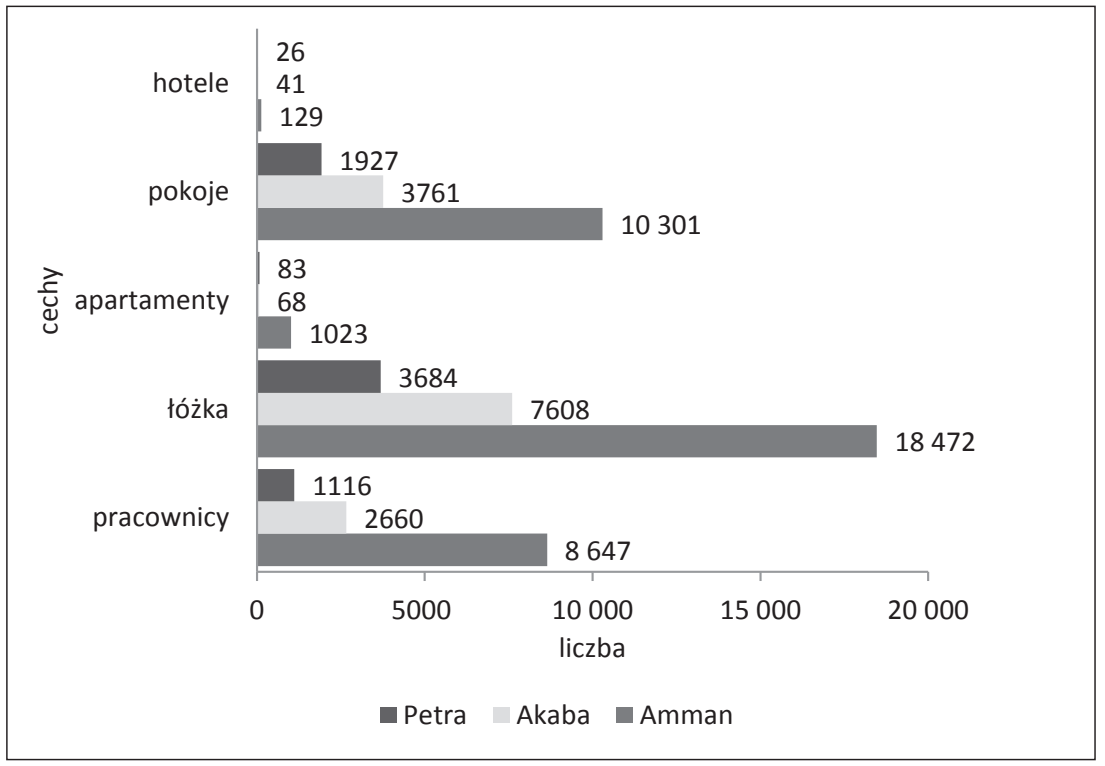

Źródło: opracowanie własne na podstawie danych Ministerstwa Turystyki Jordanii, 2014 
Jordania ma stosunkowo dobrze rozwiniętą infrastrukturę komunikacyjną, która ułatwia sprawne przemieszczanie się turystów po kraju. Znajdują się tu trzy lotniska międzynarodowe, a samoloty krajowych linii zapewniają połączenia z 59 zagranicznymi portami lotniczymi, oferującymi co tydzień ponad 500 rejsów. Jordania posiada bezpośrednie połączenie lotnicze z większością krajów zachodnioeuropejskich. W sezonie loty czarterowe wykonywane są także do Polski. Główne międzynarodowe lotnisko znajduje się w Ammanie. Loty krajowe realizowane są tylko na trasie Amman-Akaba. Jeśli chodzi o drogi kołowe, to główne znaczenie posiada droga szybkiego ruchu zwana Drogą Królewską (znana już od czasów starożytnego Egiptu jako ważny trakt handlowy), prowadząca z Ammanu do Akaby (ryc. 7).

Ryc. 7. Dostępność komunikacyjna w Jordanii

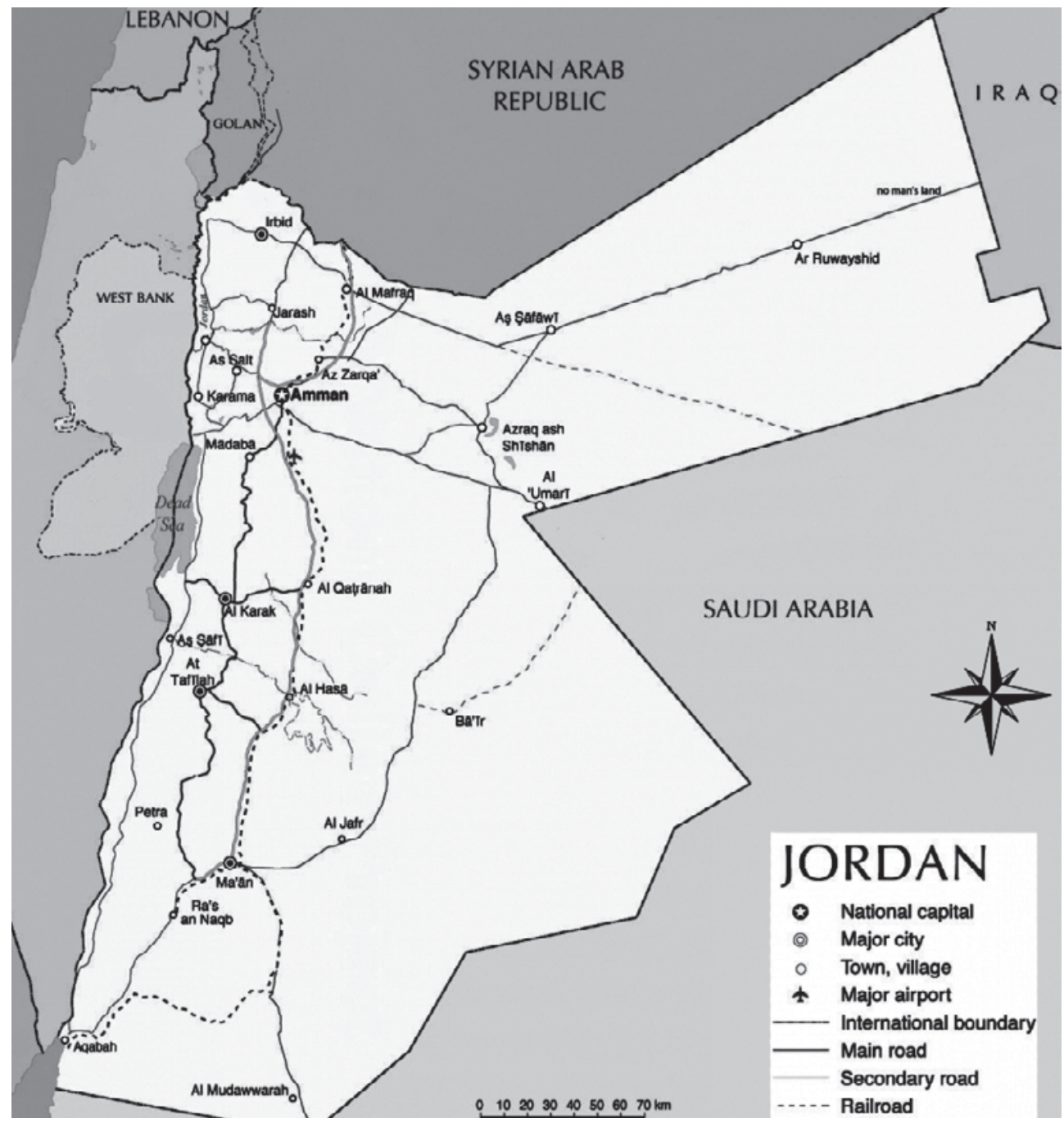

Źródło: opracowanie własne na podstawie http://www.nationsonline.org/maps/jordan-map.jpg 
Wzdłuż trasy tej są umiejscowione wszystkie najważniejsze atrakcje turystyczne Jordanii. Najdogodniejszym środkiem transportu jest autobus. W ruchu turystyki międzynarodowej ważną rolę odgrywa droga morska, którą przepływają codziennie turyści z Akaby do Nuwajbi w Egipcie.

\section{WNIOSKI}

Jordania to nie tylko kraj charakteryzujący się znaczącą destynacją turystyczną pod względem rozmaitości kulturowej czy atrakcyjnych zabytków, ale także państwo wyjątkowe z perspektywy jego położenia, zróżnicowania klimatycznego czy też różnorodności miast. Prognozy co do przyjazdów turystów zagranicznych oraz dochodów z turystyki są optymistyczne. Jordańskie władze coraz więcej pieniędzy lokują w inwestycje, które pomogą rozwinąc sektor turystyczny. Ważną rolę w rozwoju turystyki Jordanii odgrywa specjalna strefa ekonomiczna w Akabie, funkcjonująca w oparciu o bardzo korzystne dla inwestorów regulacje prawne, co stwarza dogodne warunki do podjęcia inwestycji w tym regionie. Współpraca z wieloma państwami ma na celu rozwój jordańskiego rynku turystycznego. Kraj ten, obserwując rynki turystyczne światowych potęg, dąży do uzyskania lepszej pozycji nie tylko na Bliskim Wschodzie, ale także na globalnym rynku turystycznym. Ponadto celem władz jest skuteczne promowanie kraju na światowym rynku turystycznym, które dotychczas nie było dostatecznie finansowane.

\section{Literatura}

\section{References}

Bender, F. (1974). Geology of Jordan. Contribution to the Regional Geology of the World. Berlin: Gebrueder, Bornatraeger.

Encyklopedia geograficzna świata. Azja (1998). Kraków: Wydawnictwo OPRES.

Ferreira, S., Rial, A., Varela, J. (2009). Post Hoc Tourist Segmentation with Conjoint and Cluster Analysis. Revista de Turismo y Patrimonio Cultural, 7. Wydawnictwo Pasos.

Gołembski, G. (red.). (2002). Kompendium wiedzy o turystyce. Warszawa-Poznań: PWN.

Gunn, C.A. (1972). Vacationscape: designing tourist regions. Bureau of Business Research, University of Texas at Austin.

Kowalczyk, A. (2001). Geografia turyzmu. Warszawa: PWN.

Kruczek, Z., Sacha, S. (1995). Geografia atrakcji turystycznych Polski. Kraków: Wydawnictwo Ostoja. Kurek, W. (2007). Turystyka. Warszawa: PWN.

Lijewski, T., Mikułowski, B., Wyrzykowski, J. (2002). Geografia turystyki Polski. Warszawa: PWE.

Makhlouf, I.M. (1998). Storm-generated channels in the Middle Dubaydib Sandstone Formation, South Jordan. J. King Saud Univ. 10. Science (1).

Mayhew, B. (2006). Lonely Planet - Jordan. Lonely Planet.

Medlik, S. (1995). Leksykon podróży, turystyki i hotelarstwa. Warszawa: PWN.

Meyer, B. (red.) (2010). Potencjat turystyczny: zagadnienia przestrzenne. Szczecin: Wydawnictwo Naukowe Uniwersytetu Szczecińskiego.

Nowacki, M. (2002). Uwarunkowania aktywności żeglarskiej. Poznań: Wydawnictwo AWF.

Rogalewski, O. (1979). Zagospodarowanie turystyczne. Warszawa: WSiP. 
UNWTO Tourism Highlights, 2014 edition (2014). Pozyskano z http://mkt.unwto.org/publication/unwto-tourism-highlights-2014-edition

Warszyńska, J., Jackowski, A. (1978). Podstawy geografii turyzmu. Warszawa: PWN.

Warszyńska, J. (red.) (1994). Geografia turystyczna świata. Warszawa: PWN.

http://www.dos.gov.jo/dos_home_a/main/yearbook_2013.pdf

Bożena Elżbieta Wójtowicz, dr hab., prof. nadzwyczajny, Uniwersytet Pedagogiczny, Wydział Geograficzno-Biologiczny, Instytut Geografii, Zakład Dydaktyki Geografii. Kierownik Zakładu Dydaktyki Geografii Instytutu Geografii Uniwersytetu Pedagogicznego w Krakowie. Geograf, dydaktyk geografii, podróżnik, zwiedziła większość krajów europejskich oraz Kubę, Dominikanę Meksyk, Indie, Nepal, Egipt, Maroko, Jordanię i Turcję. Opublikowała ponad 190 prac naukowych w kraju i za granicą. Autorka monografii naukowej Geografia, rozwój zrównoważony, edukacja ekologiczna oraz współautorka i redaktor prac o charakterze monograficznym, m.in.: Przyroda województwa świętokrzyskiego, Funkcje turystyki i krajoznawstwa $w$ strategii rozwojów regionów $w$ Polsce, Turystyka i ekologia - rozbudzanie potrzeb poznawczych i świadomości społeczeństwa, Ksztatcenie i doksztatcanie nauczycieli geografii $w$ Polsce $i$ w krajach Unii Europejskiej, Edukacyjne zajęcia terenowe w Świętokrzyskim Parku Narodowym. Współautorka podręczników szkolnych: Geografia. Krajobrazy Polski do klasy 4, Geografia. Ziemia - nasza planeta do klasy 6, Przyroda do klasy 4 i 5. Specjalistka z zakresu geografii, turystyki i rekreacji, dydaktyki geografii oraz ochrony środowiska.

Bożena Elżbieta Wójtowicz, Ph.D., prof. Pedagogical University of Cracow, Faculty of Geography and Biology, Institute of Geography, Department of Geography Teaching. Geographer, geography teacher, traveller, visited most of the European countries, Cuba, Mexico, Dominican Republic, India, Nepal, Egypt, Morocco, Jordan, Turkey. Head of the Department of Geography, Institute of Geography Teaching of the Pedagogical University of Cracow. She has published over 190 scientific papers in the country and abroad. The author of the monograph Geography Sustainable Development Environmental Education and co-author and editor of a monographic work, including Świętokrzyskie Voivodeship Nature, Features of tourism and sightseeing in the strategy of regional developments in Poland, Tourism and ecology - to foster the cognitive needs and public awareness, Education and training of teachers of geography in Poland and in the European Union, Educational fieldwork in Świętokrzyski National Park. Co-author of textbooks: Geography. Polish Landscapes Class 4, Geography. Earth our planet to Grade 6, Nature Class 4 and 5. Specialist in the field of geography, tourism and recreation, teaching geography and the environment.

\section{Adres/address:}

Uniwersytet Pedagogiczny

Wydział Geograficzno-Biologiczny

Instytut Geografii

Zakład Dydaktyki Geografii

ul Podchorążych 2, 30-084 Kraków, Polska

e-mail:boz.wojt@gmail.com

Pawel Wójtowicz, matematyk ze specjalnością zastosowanie matematyki w finansach i teleinformatyce, podróżnik, zwiedził większość krajów Europy oraz Dominikanę, Maroko, Kubę i Jordanię. Były pracownik Centrum Obsługi Informatycznej Uniwersytetu Pedagogicznego w Krakowie. Współorganizator XI Międzynarodowej Olimpiady Geograficznej, odpowiedzialny za obsługę informatyczną, techniczną oraz organizacyjną. Opublikował kilka prac naukowych w kraju i za granicą, m.in. Wadi Rum Desert as Object geotouristic Jordan, The use of Geographical Information Systems (GIS) in education in college academic geographical examples of selected universities in Poland, Cultural tourist attractiveness of Milan, in the Opinion of Polish Tourists. Specjalista z zakresu matematyki, informatyki oraz turystyki i rekreacji. 
Pawel Wójtowicz, studied mathematics, with a specialization in the use of mathematics in finance and teleinformatics, traveller, visited most of the countries of Europe and Dominican Republic, Morocco, Cuba and Jordan. A former employee of UP Informatics Centre in Krakow. Co-organizer of the International XI Olympics, where he was responsible for IT, technical and organizational services. He has published several research papers in the country and abroad, for example: Wadi Rum Desert as Object geotouristic Jordan, The use of Geographical Information Systems (GIS) in education in college academic geographical examples of selected universities in Poland, Cultural tourist attractiveness of Milan, in the Opinion of Polish Tourists.

\section{Adres/address:}

NETLIER Paweł Wójtowicz

ul. Tadeusza Kościuszki 33/5, 25-316 Kielce, Polska

e-mail: pwojtowicz@netlier.pl 